\title{
Does biogeography have a future in a globalized world with globalized faunas?
}

\author{
Frederick R. Schram \\ Burke Museum, University of Washington, Seattle, P.O. Box 1567, Langley, WA 98260, USA, \\ fschram@u.washington.edu
}

Key words: Anaspidacea, Bathynellacea, globalization, historical biogeography, vicariance

\begin{abstract}
The study of biogeography was once a pillar of evolution science. Both Darwin and especially Wallace found great inspiration from the consideration of animal distributions. However, what is to happen to this discipline in a time of global trade, mass movement of people and goods, and the resulting globalization of the planet's biota? Can we still hope to delve into the fine points of past geography as it affected animal and plant evolution? Maybe we can, but only with careful study of life forms that suffer minimal affects - at present - from globalization, viz., marginal faunas of quite inaccessible environments. Two examples taken from syncarid crustaceans illustrate this point. Bathynellacea provide insight into ancient patterns of distribution and possible modes of evolution of that group. Modern Anaspididae yield some surprising information concerning the timing of evolutionary events.
\end{abstract}

\section{Contents}

Introduction ……........................................................... 127

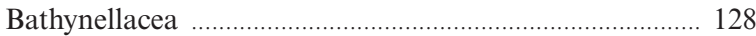

Anaspidacea …............................................................. 130

Unanswered questions ........................................................ 131

Conclusions ..................................................................... 132

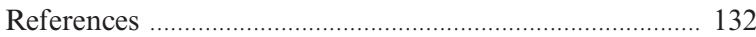

\section{Introduction}

The globalization of the world's economy finds an equivalent in the biological realm - a globalization of the world's biota. Scientific journals and news media are filled with such examples - now in the realm of common knowledge. The invasive amphipod Dikerogammarus vilosus into Western Europe from the Pont-Caspian is only one example of what is an on-going phenomenon. The Great Lakes of North America have become a poster child of the effects of invasive organisms. There are now some 160 alien species of animals, plants, and pathogens in the Great Lakes and it is said that a new invader species is identified every eight months. The toll on the fisheries of the Great Lakes alone has been devastating. Another example is San Francisco Bay, where some 234 invasive species have been recorded up to the present day, i.e., something like $90 \%$ of the aquatic population of the bay. Finally, the infamous Chinese mitten crab, Eriocheir sinensis, is conducting an on-going assault on Chesapeake Bay, and the effect on the native blue crab populations is already being measured. In the United States, invading arthropods (insects as well as crustaceans) cause over $\$ 2$ billion in damages.

While local ecologies manifest the impact of faunal globalization, a more esoteric discipline also suffers impact - the fate of the science of biogeography. In groups and in areas that until now have been little studied, we find ourselves about to lose the capacity to pursue the science of biogeography. We often lack the base data concerning the distribution of native species before globalization began, and consequently it is difficult to assess the effects of the invaders. Indeed, we often do not know if we are looking at a legitimate range extension of taxa heretofore not well studied, or if we are merely taking note of the results of a new introduction to an area from the ballast tanks of the world's commercial shipping.

Even so, historically the careful study of the fauna and flora of the world has been crucial to understanding the history of the planet's crust and the evolution of life itself. For good reason did Alfred Russel Wallace become a key player in elucidating evolution by natural selection; it was his long-standing interest in the distribution of animals that provided critical insights that enabled him to independently arrive at the same conclusions about evolution as Charles Darwin.

Does globalization mean that biogeography as a science is dead? We should probably answer 'yes', at 
least with regard to macrofauna, i.e., we have arrived at a point in time when we can no longer be certain of what we are actually seeing in nature (although phylogeography may yet allow us to trace the 'history' of invasive organisms using molecular techniques). However, there may be a ray of hope. I believe it is still possible, in special circumstances, to study the history of the earth's crust directly and gain meaningful knowledge about evolution with reference to some of its biota. We simply have to be careful to select animal groups and sample habitats that have sustained minimal impact from invasion. Indeed, the examples below might be characterized as from marginal faunas in relatively inaccessible environments. So be it; that is the price we pay for globalization.

The title of this contribution is worth a book length treatment. Hence, the purpose of this short review is to present only a few examples of how one group of crustaceans, the syncarid eumalacostracans, can serve in this regard. They function well because they exhibit several criteria. First, they represent ancient lineages. The living Anaspidacea undoubtedly are related to the Late Paleozoic Palaeocaridacea. The microscopic Bathynellacea have no fossil record, but their patterns of distribution indicate ancient Paleozoic roots in Pangaea and prePangaea. Second, members of these two orders are of a physical size and are ecological generalists such that they remain unobtrusive, i.e., they do not draw the attention of potential predators, and are thus able to avail themselves of a broad spectrum of available resources in their surroundings. Third, these animals typically occupy rather cryptic habitats, e.g., interstitial spaces in muddy or sandy bottoms, caves, and ground water. Fourth, their powers of dispersal are limited. In fact, I believe these features (ancient age, generalists, cryptic habitats, and limited powers of dispersal) constitute the criteria we must seek in other animal groups and which might serve to outflank faunal globalization.

Let us examine some case studies from each group.

\section{Bathynellacea}

These crustaceans are small organisms ranging in size from 1-3 mm as adults (see Schram, 1986). They live in the spaces between sediment grains and apparently graze on bacterial, algal, and fungal films.
Their tiny size and limited number of trunk limbs insures limited powers of dispersal; I suspect that under normal circumstances a bathynellacean lives and dies probably within $5-10 \mathrm{~mm}$ of where it hatched. The group was first recognized and described in the late 1800s (Bathynella natans Vejdovsky, 1882), but it was not until numerous species entered the literature, due largely to the efforts of Eugene Serban, Wolfram Noodt, and Kurt Schminke, that certain biogeographic patterns became evident. Schminke (1974) was the first to draw attention to these patterns. While most genera and species of bathynellaceans are highly endemic, a few genera have extended ranges, e.g., Cteniobathynella occurs in Brazil and central Africa, Notobathynella is found in Australia and New Zealand, and Chilibathynella and Atopobathynella occur in Australia and in Chile. A general consideration of what was known at the time resulted in Schminke (1974) postulating a dispersal of the parabathynellids from a hypothetical center of origin in East Asia along three pathways: 1) to Europe, 2) to Africa and on to eastern South America, and 3) to Southeast Asia, then to Austral$\mathrm{ia} /$ New Zealand, and on to western South America. Schram (1977) examined the distribution of fossil malacostracans in the Paleozoic and postulated a different scenario, viz., that the group as a whole appears to have taken origin on the island continent of Laurentia and dispersed through out the world with the formation of Pangaea in the Late Paleozoic. In Schminke's analysis, several areas of the world were noteworthy because of their apparent lack of bathynellaceans (India, South Africa, and - most peculiar of all - all of North America); but these areas in the intervening years have now all been found to have bathynellaceans, so the group as a whole is ubiquitous.

A genus of special interest, however, is Hexabathynella, because, in an order noted for local and regional endemism, this genus is the only bathynellacean taxon that occurs worldwide. Camacho (2003) analyzed the group, which at that time contained 18 species, and her cladogram (Fig. 1) revealed two interesting patterns.

The first pattern relates to the affinities of the sub-clades. The Hexabathynella of the Balkans are nested amongst the southern hemisphere clades, while those of Western Europe exhibit a sister status to the North American species. While the Balkans often yield interesting and peculiar taxa in many groups, this supposed Gondwana connection is 
Fig. 1. Relationships of 18 species of Hexabathynella modified from Camacho (2003).

* indicate the 5 species from brackish-marine habitats.

- indicate the necessary 7 independent invasions of terrestrial habitats if Hexabathynella originated in a marine habitat.

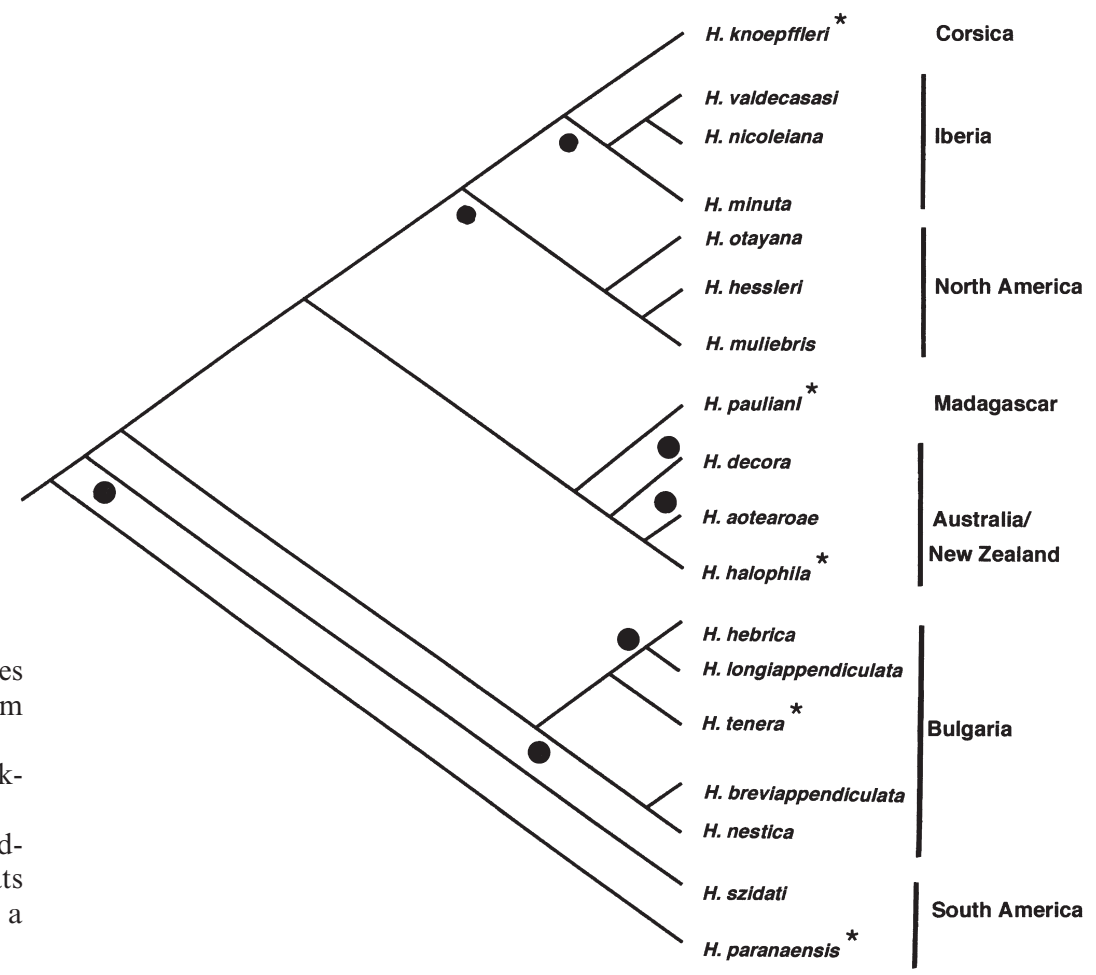

noteworthy. The second pattern relates to hypotheses about the evolution of the genus, and by extension perhaps the whole order. The basal-most species on her cladogram, $H$. paranaensis from Brazil, is one of five brackish to marine species in the genus. Because of this, and on theoretical grounds, Camacho reasoned that Hexabathynella most likely took origin in the marine realm and then radiated onto the continents.

This pattern conformed to what she termed the Thallasoid Theory (Boutin and Coineau, 1990), which is actually a later version of the Regression Theory of Stock (1980). Under the terms of this hypothesis, forms that are marine in origin became stranded in fresh water when sea level regressed. The opposing hypothesis is the so-called Limnicoid Theory (Schminke, 1981), which assumes that the primary origin occurs in fresh water, with subsequent invasions into marginal brackish and marine habitats. As far as bathynellaceans are concerned, the widespread manifestation of freshwater habitats in the order as a whole might argue for this latter theory.

Nevertheless, these opposing hypotheses can be tested on the cladogram. If a marine origin of Hexabathynella occurred, then the tree in Fig. 1 tells us that there had to have been 7 independent invasions of fresh water from the marine/brackish water realm. If the origin of Hexabathynella took place in fresh water, then only 5 independent invasions of salt water would be needed, one for each of the 5 species. Thus, the limnicoid explanation appears more parsimonious.

Moreover, for any cladistic analysis the relationships on the tree itself can be tested with the identification of new species and their incorporation into the analysis. Cho and Schminke (2006) did that when they added four new species of Hexabathynella into their cladistic analysis of the genus. A somewhat different set of relationships emerged from their work (Fig. 2).

With regard to the patterns seen in the 2006 tree, two observations can again be made. First, all the European and North American taxa now occur together in a series of sister clades, whereas the Gondwana clades cluster together nearer the base of the cladogram, a more logical historical patterning that suggests a possible origin of Hexabathynella in the southern land masses with subsequent dispersal into the northern hemisphere in Paleozoic times. Second, we can again test hypotheses of marine versus freshwater origins. If Hexabathynella has a ma- 
Fig. 2. Relationships of 22 species of Hexabathynella modified from Cho and Schminke (2006).

* indicate the 5 species from brackish-marine habitats.

- indicate the necessary 8 independent invasions of terrestrial habitats if Hexabathynella originated in a marine habitat.

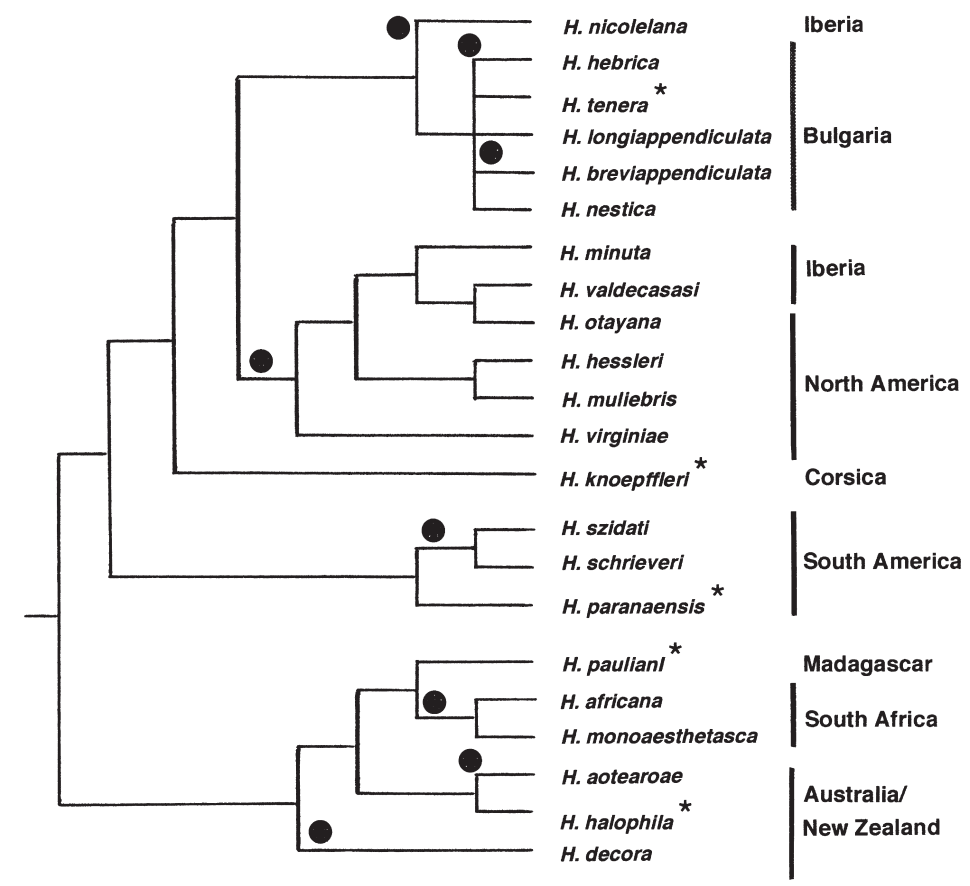

rine origin, then the $\mathrm{Cho} / \mathrm{Schminke}$ tree reveals that at least 8 invasions of freshwater had to have occurred. If Hexabathynella has a freshwater origin, the same 5 invasions of salt water occurred as seen on the Camacho tree. Therefore, the Cho/Schminke cladogram implies an even more parsimonious likelihood that Hexabathynella arose in fresh water.

We see in the above simple examples that classic, area cladistic, analysis combined with a careful attention to determining parsimony can pay dividends, enabling us to solve this particular biogeographic problem and sort out the conflicting hypotheses about the evolution of this group. Naturally, the arguments could be strengthened if we had a comprehensive cladistic analysis of the entire array of Bathynellacea. That, however, is not available at this time. Moreover, such an analysis could then allow a deeper exploration of paleobiogeography of the bathynellaceans as a whole.

\section{Anaspidacea}

The order Anaspidacea has long fascinated carcinologists. The group was known from the fossil record, with the description of Uronectes fimbriatus (Jordan, 1847) from the Permian of Bohemia, a long time before the first living form, Anaspides tasmaniae Thomson, 1892, was recognized. Calman (1917) was the first to suggest a link between that fossil and the at-that-time newly redescribed Bathynella natans as well as the Tasmanian mountain shrimp, A. tasmaniae. Indeed, Uronectes fimbriatus was the first described species of what came to be acknowledged as a diverse radiation of 'palaeocaridaceans' in the Paleozoic. However, cladistic analyses (currently underway) reveal that the socalled 'order' Palaeocaridacea constitutes a paraphyletic series of stem families that lead to the crown group Anaspidacea. One Triassic fossil from New South Wales, Anaspidites antiquus (Chilton, 1929), is in fact assigned to the anaspidines and another fossil from the Cretaceous of Victoria, Koonaspides indistinctus Jell and Duncan, 1986, appears to also lie within the anaspidines.

However, what the distribution of the modern representatives of the family Anaspididae tells us leads us to question whether everything about Anaspidacea can be related to the status as a socalled 'living fossil' (Schram and Hessler, 1984). Anaspididae occurs only on Tasmania, extending from the central plateau down into the south and southwestern sections of the state. Four species have been recognized: Anaspides tasmaniae (originally 
described from Mt. Wellington but thought to be widespread across the island), Paranaspides lacustris Smith, 1909 (restricted to certain lakes on the central plateau), and Allanaspides hickmani Swain, Wilson and Ong, 1970 and A. helonomus Swain, Wilson, Hickman and Ong, 1970 (restricted to the region around Lakes Pedder and Gordon in the southwest). A fifth species Anaspides spinulae Williams, 1965 (from Lake St. Claire) has generally found little acceptance, most authorities considering it a morphological variant of $A$. tasmaniae.

Jarman and Elliott (2000) examined 16S rDNA sequences and uncovered a diverse radiation within the genus Anaspides, with at least three 'species' clades indicated: their 'species 1' clade containing the type locality of $A$. tasmaniae and the controversial $A$. spinulae, and the clades of 'species $2+3$ ' being quite distinct (see Jarman and Elliot, 2000, fig. 4) from species.

Subsequently, Andrew (2004) conducted electrophoretic studies of an array of populations from across the island of all the species of anaspidids and uncovered similar, though slightly different, results to those of Jarman and Elliott: a set of southern populations that accorded well with 'species 1', southwestern populations that accorded with 'species 2', an array of central plateau populations that include the type locality for $A$. spinulae, and finally the separate Mt. Wellington type locality for A. tasmaniae.

The number of new species necessary to accommodate this molecular diversity remains to be determined (Ahyong, personal communication). Of special interest, however, are the molecular clock estimates for times of divergence (Tables $1 \& 2$ ). While the limited fossil material indicates Mesozoic ori-

Table 1. Molecular clock estimates of times of divergence of species of Anaspididae on Tasmania, modified from Jarman and Elliott (2000).

\begin{tabular}{|c|c|}
\hline Divergence events of taxa & $\begin{array}{l}\text { Tean estimate of time } \\
\text { millions of years }\end{array}$ \\
\hline ancestor of Anaspididae & 37.32 \\
\hline $\begin{array}{l}\text { divergence of Allanaspides spp. } \\
\text { divergence of Anaspides sp. 1,+ }\end{array}$ & 26.33 \\
\hline Anaspides spp. $2 \& 3,+$ Paranaspides & 25.01 \\
\hline ancestor of Anaspides spp. $1+2$ & 7.88 \\
\hline ancestor of Anaspides sp. 2 & 5.29 \\
\hline ancestor of Anaspides sp. 3 & 4.60 \\
\hline ancestor of Anaspides sp. 1 & 2.51 \\
\hline
\end{tabular}

gins for the anaspidines, the clock estimates place the radiation of known Anaspididae well within the Tertiary.

At face value, it would appear that the Tasmanian anaspidids might not be 'living fossils' at all. A careful examination of the phylogeography of the living anaspidids reveals that in this supposedly ancient group, the speciation actively going on is a rather young event - of an order of 10s of millions of years rather hundreds of millions of years.

\section{Unanswered questions}

Not everything about the syncarids is clear. The vicariant patterns of intercontinental biogeographic links of these animals are also intriguing. For example, something peculiar (Fig. 3) seems to going on in South America with the distribution of both Bathynellacea as well as stygocaridine Anaspidacea (Lopretto and Marrone, 1998). Noodt (1978) was the first to comment on this disparity, observing that it appeared as if bathynellaceans had taken two different paths to occupy South America.

Several taxa link Australia, New Zealand, and the southern Andes. The genus Stygocaris has species that extend from Australia, through New Zealand, to Chile, and this pattern is paralleled by species of the virtually ubiquitous genus Bathynella. Similarly, the genus Atopobathynella has representatives in southeastern Australia, Tasmania, New Zealand, and Chile. Chilibathynella can be collected in southeastern Australia and Chile. Obviously, this link across the southern Pacific is a manifestation of an ancient path of dispersal, or vicariant track, that utilized Antarctica when Gondwanaland was intact.

Table 2. Molecular clock estimates of times of divergence of species of Anaspididae on Tasmania, modified from Andrew (2004).

\begin{tabular}{lc}
\hline Divergence events of taxa & $\begin{array}{l}\text { Mean estimate of time } \\
\text { in millions of years }\end{array}$ \\
\hline $\begin{array}{l}\text { divergence of Allanaspides } \\
\text { divergence of Paranaspides }+\end{array}$ & 43 \\
$\quad$ southern Anaspides & 20 \\
divergence of southwestern Anaspides & 10 \\
differentiation within southwestern Anaspides 6 \\
differentiation within southern Anaspides & 3.5 \\
differentiation within differentiation within & \\
$\quad$ southern Anaspides Anaspides & 2 \\
split of spp.within Allanaspides & 0.35 \\
\hline
\end{tabular}


Fig. 3. Vicariant patterns of syncarid distributions in the southern hemisphere (from Lopretto and Morrone, 1998). Two tracks prevail: one apparently across the South $\mathrm{Pa}$ cific, a relict of a pathway through Antarctica, and the other traversing the South Atlantic.

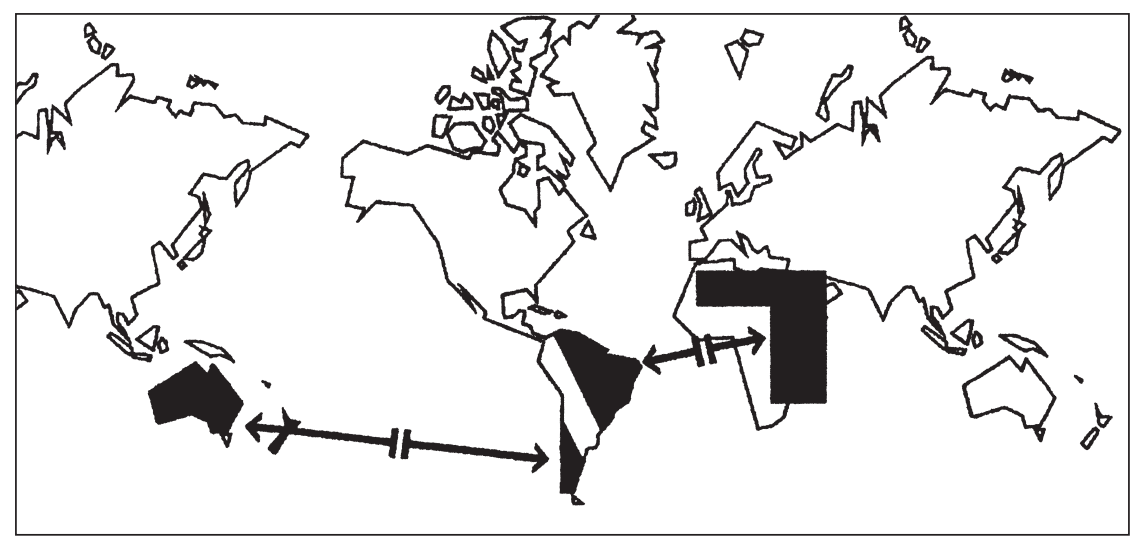

This South Pacific pattern contrasts with a different set of bathynellacean taxa that link northeastern and eastern South America with Africa. Specifically, the genera Nannobathynella and Cteniobathynella have members in Brazil as well as Central Africa. This latter track represents the remnants of a pre-Atlantic union of that part of South America with Africa before the opening of the South Atlantic seaway.

There appears to be a peculiar disparity here. Gondwanaland began breaking apart 100 million years ago. Why, in all that time, have not the eastern/northeastern groundwater biotas of South America mixed with those of the southern Andes and southern freshwater basins of South America? What is the barrier across the central belt of South America that has inhibited this exchange? Right now, these are unanswered questions that must await further examination of the groundwater biota and paleogeography of South America.

\section{Conclusions}

Does biogeography have a future in a globalized world with globalized faunas? Perhaps, but it is a limited one. Despite the globalization of world trade acting to homogenize the planet's biota, there are, nevertheless, groups of organisms that are not yet globalized, and may never be globalized - marginal faunas from quite inaccessible environments. I have offered only a few select examples from one particular group of crustaceans, the syncarids, upon which the effects of globalization are still insignificant to non-existent. At least for the time being, it appears that habitats such as interstitial freshwaters, ground water, and caves can provide relatively untouched environments for study. Crustaceans are not the only groups that lend themselves to these efforts, see Boyer et al. (2007). Nevertheless, these efforts can only be undertaken if we can satisfy certain criteria. The taxa studied must: 1) be of a demonstrated ancient lineage, 2) be ecological generalists, 3) live in cryptic habitats, and 4) have limited abilities to disperse. Only under these conditions can the effects of globalization be circumvented and will the science of biogeography have a future.

\section{References}

Andrew J. 2004. Biogeography and Systematics of the Tasmanian Mountain Shrimp Anaspides tasmaniae Thomson, 1892 (Syncarida: Anaspididae). MSc. thesis. Hobart, University of Tasmania.

Boutin C, Coineau N. 1990. Regression model, modèle biphase d'évolution et origine des micro-organismes stygobies interstitiels continentaux. Revue de Micropaléontologie 33: 303-322.

Boyer SL, Clouse RM, Benavides LR, Sharma P, Svendinger PA, Karunarathna I, Giribet G. 2007. Biogeography of the world: a case study from cyphothalmid Opiliones, a globally distributed group of arachnids. Journal of Biogeography 34: 2070-2085.

Calman WT. 1917. Notes on the morphology of Bathynella and some allied Crustacea. Quarterly Journal of the Microscopical Society 62: 489-514.

Camacho A. 2003. Historical biogeography of Hexabathynella, a cosmopolitan genus of groundwater Syncarida (Crustacea, Bathynellacea, Parabathynellidae). Biological Journal of the Linnean Society, London 78: 457-466.

Chilton C. 1929. Note on a fossil shrimp from Hawkesbury sandstones. Journal of the Royal Society of New South Wales 62: 366-368.

Cho J-L, Schminke HK. 2006. A phylogenetic review of the genus Hexabathynella Schminke, 1972 (Crustacea, Malacostraca, Bathynellacea): with a description of four new 
species. Zoological Journal of the Linnean Society, London 147: 71-96.

Jarman SN, Elliott NG. 2000. DNA evidence for morphological and cryptic Cenozoic speciations in the Anaspididae, 'living fossils' from the Triassic. Journal of Evolutionary Biology 13: 624-633.

Jell PA, Duncan PM. 1986. Invertebrates, mainly insects, from the freshwater, Lower Cretaceous, Koonwarra Bed (Korumburra Group), South Gippsland, Victoria. Memoirs of the Association of Australasian Palaeontologists 3: 111-205.

Jordan H. 1847. Entdeckung fossiler Crustaceen in Saarbrückenschen Steinkohlengebirge. Verhandlungen des naturhistorischen Vereins der Preussischen Rheinlande und Westfalens, Bonn 4: 89-92.

Lopretto EC, Morrone JJ. 1998. Anaspidacea, Bathynellacea (Crustacea, Syncarida), generalized tracks, and the biogeographical relationships of South America. Zoologica Scripta 27: 311-318.

Noodt W. 1978. Syncarida. In: Hurlbert H ed. Biota Acuática de Sudamérica Austral. San Diego: San Diego State University, 146-148.

Schminke HK. 1974. Mesozoic intercontinental relationships as evidenced by bathynellid Crustacea (Syncarida: Malacostraca). Systematic Zoology 23: 157-164.

Schminke, HK. 1981. Perspectives in the study of zoogeography of interstitial Crustacea. Bathynellacea (Syncarida) and Parastenocarididae (Copepoda). International Journal of Speleology 11: 83-89.

Schram FR. 1977. Paleozoogeography of late Paleozoic and Triassic Malacostraca. Systematic Zoology 26: 367-379.
Schram FR. 1986. Crustacea. New York: Oxford University Press.

Schram FR, Hessler RR. 1984. Anaspidid Syncarida. In: Eldredge N, Stanley SM eds. Living Fossils. New York: Springer, 192-195.

Smith GW. 1909. On the Anaspidacea, living and fossil. Quarterly Journal of Microscopical Science 53: 489-578.

Stock J. 1980. Regression model evolution as exemplified by the genus Pseudoniphargus (Amphipoda). Bijdragen tot de Dierkunde 50: 105-144.

Swain R, Wilson IS, Ong JE. 1970. A new species of Allanaspides (Syncarida, Anaspididae) from south-western Tasmania. Crustaceana 21: 196-202.

Swain R, Wilson IS, Hickman JL, Ong JE. 1970. Allanaspides helonomus gen. et sp. nov. (Crustacea: Syncarida) from Tasmania. Records of the Queen Victoria Museum 35: $1-13$.

Thomson, GM. 1892. Notes on Tasmanian Crustacea, with descriptions of new species. Proceedings of the Royal Society of Tasmania 1: 45-76.

Vejdovsky F. 1882. Thierische Organismen der Brunnengewässer von Prag. Prague.

Williams WD. 1965. Ecological notes on Tasmanian Syncarida (Crustacea: Malacostaca), with a description of a new species of Anaspides. Internationale Revue der gesamten Hydrobiology 50: 95-126.

Accepted: 15 December 2007

Received: 25 June 2008 
